\title{
Pemodelan dan Peramalan Harga Penutupan Saham Perbankan dengan Metode ARIMA dan Family ARCH
}

\author{
Dewi Novanti ${ }^{1}$, Hajrul Multazam ${ }^{2 *}$, Novira Laily Husna ${ }^{3}$, Ossy Sanityasa \\ Rahajeng $^{4}$, Selfina L. ${ }^{5}$, Rani Nooraeni ${ }^{6}$ \\ 1,2,3,4,5,6 Jurusan Statistika Peminatan Sosial Kependudukan \\ Politeknik Statistika STIS, Indonesia \\ * Corresponding author, email: 211709727@stis.ac.id
}

\begin{abstract}
Modelling the stock closing price stock is useful so that the investors are expected to be able to understand the situation of the stock, in order to make the right decision when they want to buy or sell their stocks. This study uses the ARIMA and Family ARCH methods in modelling the volatility of four banking stocks that are in high demand by the public, which are Bank BRI (BBRI), Bank BNI (BBNI), Bank Mandiri (BMRI), and Bank BCA (BBCA) from January $1^{\text {st }} 2017$ until January 31 st 2020. Stock returns are modelled by using the ARIMA model, then proceeded with the heteroscedasticity testing. Based on the test, we obtained the results of BBRI, BMRI, and BBCA are heteroscedastic. While BBNI are homoscedastic. The volatility models obtained from the test are BBNI has ARIMA models ([6,13], 1, [6,13]), BBRI has ARI models ([2,24,28), 1,0)-ARCH (1), BMRI has an ARIMA (2,1,4)-GARCH $(1,1)$ model, and BBCA has ARI ([1,2], 1,0)-GARCH (1,1) model. Based on the rising value of the stock price, we suggest the best stock for the investors is BBRI because it has the largest increase of $10 \%$ followed by $B B C A$ and BMRI.
\end{abstract}

Keywords: ARCH-GARCH, ARIMA, Banking Stocks, Return, Volatility.

\begin{abstract}
Abstrak
Pemodelan data closing price saham berguna agar investor investor diharapkan mampu untuk mempelajari situasi saham, sehingga dapat mengambil keputusan yang tepat ketika melakukan pembelian maupun penjualan atas saham yang dimiliki. Penelitian ini menggunakan metode ARIMA dan Family ARCH dalam memodelkan volatilitas empat saham perbankan yang sangat diminati oleh masyarakat, yaitu Bank BRI (BBRI), Bank BNI (BBNI), Bank Mandiri (BMRI), dan Bank BCA (BBCA) selama periode 1 Januari 2017 hingga 31 Januari 2020. Return saham dimodelkan terlebih dengan model ARIMA, kemudian dilanjutkan dengan pengujian heteroskedastisitas. Diperoleh hasil saham BBRI, BMRI, dan BBCA bersifat heteroskedas. Sedangkan saham BBNI bersifat homoskedas. Model volatilitas yang diperoleh yaitu saham BBNI memiliki model ARIMA([6,13],1,[6,13]), saham BBRI memiliki model ARI([2,24,28),1,0)-ARCH(1), saham BMRI memiliki model ARIMA(2,1,4)-GARCH(1,1), dan BBCA memiliki model ARI([1,2],1,0)-GARCH(1,1). Berdasarkan nilai kenaikan harga saham, maka saham terbaik yang kami saranlan untuk dipilih oleh investor adalah saham BBRI karena memilik kenaikan terbesar yaitu sebesar 10\% diikuti oleh saham BBCA dan BMRI.
\end{abstract}

Kata Kunci: ARCH-GARCH, ARIMA, Saham Perbankan, Return, Volatilitas.

Estimasi: Journal of Statistics and Its Application e-ISSN: 2721-3803, p-ISSN: 2721-379X

http://journal.unhas.ac.id/index.php/ESTIMASI 


\section{Pendahuluan}

Pada zaman yang semakin melek teknologi, telah terjadi pergeseran pola pikir dalam mengelola keuangan. Pada zaman dahulu, masyarakat cenderung mengelola keuangan dengan cara menabung. Bahkan sudah diterapkan kepada anak-anak untuk selalu menabung. Meski begitu, keuntungan dari bunga menabung tidak dapat memberikan passive income yang mampu mencukupi kebutuhan manusia yang semakin meningkat. Oleh karena itu, trend mengelola keuangan di tahun 2019 adalah dengan cara menambah passive income melalui investasi. Dilansir dari CNBC Indonesia, sepanjang tahun 2019, investor di pasar modal Indonesia tumbuh signifikan dibandingkan dengan tahun sebelumnya. Seluruh investor tumbuh 53,04\% yang terdiri dari investor saham, reksa dana, dan surat berharga negara (SBN). Banyak yang belum mengetahui perbedaan antara saham dan reksa dana. Secara garis besar, investasi menggunakan reksa dana memiliki potensi risiko yang lebih rendah dari saham dan tentunya dengan potensi imbal hasil (return) yang lebih rendah pula. Return reksa dana yang lebih rendah dikarenakan adanya bagi hasil keuntungan antara investor dengan Manajer Investasi. Manajer Investasi memiliki tugas untuk memilih saham yang paling tepat dengan spesifikasi yang diinginkan investor, sehingga investor tidak perlu meluangkan banyak waktu dalam mencari saham terbaik yang diinginkan. Sementara investasi dalam saham, investor tidak dibekali dengan Manajer Investasi sehingga investor harus menjadi Manajer Investasi bagi dirinya sendiri. Oleh karena itu, saham memiliki potensi risiko yang tinggi dengan return yang tinggi. Cara untuk mendapatkan saham terbaik adalah dengan memilih saham yang memiliki perubahan harga saham tertinggi berdasarkan data hasil peramalan.

Berdasarkan data dari CNBC Indonesia, jumlah investor saham dari awal Januari 2019 hingga 27 Desember 2019 tercatat mencapai 1.10 juta, adapun untuk investor reksa dana jumlahnya mencapai 1.76 juta investor. Tingginya investor reksa dana di Indonesia disebabkan karena kebanyakan masyarakat Indonesia yang tidak berani untuk mengambil risiko dikarenakan takut dalam memilih langkah. Kebanyakan investor di Indonesia merupakan investor pemula, sehingga seringkali investor harus menentukan sendiri waktu yang tepat untuk menjual atau membeli saham. Saham perbankan adalah salah satu saham yang diminati di Indonesia. Dilansir dari CNN, Perry Warjiyo selaku Gubernur Bank Indonesia mengatakan bahwa hal ini terjadi karena adanya kebijakan pelonggaran Loan to Value (LTV), untuk menurunkan uang muka kendaraan bermotor dan properti demi merangsang permintaan kredit. Kinerja kredit yang diproyeksikan membaik tersebut akan menjadi katalis positif bagi saham perbankan dan tentunya akan membuat saham perbankan semakin menarik untuk dimiliki. Sejauh ini terdapat 4 bank yang memiliki saham yang sangat diminati oleh masyarakat, yaitu Bank BRI, Bank BNI, Bank Mandiri dan Bank BCA. Dari keempat saham perbankan tersebut, tentunya diperlukan suatu metode analisis yang akan membantu investor dalam menentukan saham perbankan pilihannya. 
Penelitian ini lebih mementingkan untuk meramal dibandingkan dengan mengetahui variabel yang signifikan dikarenakan variabel yang mempengaruhi perubahan harga saham tidak dipublikasikan karena bersifat sensitif. Kemudian akan dijelaskan mengenai beberapa metode yang dapat digunakan untuk memodelkan dan meramalkan harga saham menggunakan metode ARIMA dan Family ARCH. Family ARCH terdiri dari beberapa diantaranya model ARCH, GARCH, GJR-GARCH, TGARCH dan APARCH. Metode tersebut digunakan karena tipe data harga saham memiliki volatilitas yang tinggi, sehingga paling sesuai untuk dimodelkan dengan menggunakan ARIMA dan Family ARCH. Kelebihan metode ARIMA yaitu memiliki tingkat akurasi peramalan yang cukup tinggi. Sedangkan pada metode ARCH memiliki kelebihan untuk dapat mengolah data dengan karakteristik heteroskedastik, dimana hal ini tidak dapat dimodelkan dengan menggunakan model lain tanpa harus dilakukan transformasi terlebih dahulu. Ketika dilakukan transformasi data heteroskedastik menjadi homoskedastik akan terjadi hilangnya informasi, sehingga metode Family ARCH merupakan pilihan model yang tepat untuk digunakan saat model ARIMA tidak dapat mengakomodasi.

Selanjutnya, penelitian ini diharapkan mampu membantu investor untuk mempelajari situasi saham, sehingga dapat mengambil keputusan yang tepat ketika ingin melakukan pembelian maupun penjualan atas saham yang dimiliki. Setelah mampu memodelkan data closing price saham, investor tidak memerlukan Manajer Investasi untuk mengelola saham, sehingga dapat meminimalkan resiko dan dapat menghasilkan nilai return yang tinggi. Oleh karena permasalahan diatas, penulis tertarik untuk melakukan suatu penelitian tentang pemodelan dan peramalan harga penutupan saham perbankan dengan metode ARIMA dan Family ARCH.

\section{Material dan Metode}

Model ARIMA merupakan model gabungan antara Autoregressive (AR) orde $p$ dan Moving Average (MA) orde $q$ serta proses differencing orde $d$ untuk data pada level musiman maupun non musiman dan termasuk dalam kelompok pemodelan linier. Model AR (Autoregressive) pada orde $p$ menyatakan pengamatan pada waktu ke- $t$ berhubungan linier dengan pengamatan waktu sebelumnya $t-1, t-2, \ldots, t-p$. Bentuk fungsi persamaan untuk model AR pada orde $p$ dinyatakan sebagai berikut:

$$
Z_{t}=\phi_{1} Z_{t-1}+\phi_{2} Z_{t-2}+\cdots+\phi_{p} Z_{t-p}+a_{t}
$$

Model MA (Moving Average) digunakan untuk menjelaskan suatu kejadian bahwa suatu pengamatan pada waktu $t$ dinyatakan sebagai kombinasi linier dari sejumlah residual. Bentuk fungsi persamaan untuk model MA pada orde $q$ dinyatakan sebagai berikut:

$$
Z_{t}=a_{t}-\theta_{1} a_{t-1}-\theta_{2} a_{t-2}-\cdots-\theta_{q} a_{t-q}
$$

Model ARMA merupakan model gabungan antara model AR (Autoregressive) dan MA (Moving Average) yang kadang ditulis dengan notasi ARMA $(p, q)$. Bentuk fungsi model ARMA pada orde $p$ dan $q$ dinotasikan sebagai berikut: 


$$
Z_{t}=\phi_{1} Z_{t-1}+\cdots+\phi_{p} Z_{t-p}+a_{t}-\theta_{1} a_{t-1}-\cdots-\theta_{q} a_{t-q}
$$

Model ARIMA $(p, d, q)$ yang dikenalkan oleh Box dan Jenkins dengan $p$ sebagai orde operator dari AR, $d$ merupakan orde differencing dan $q$ sebagai orde operator dari MA. Model ini digunakan untuk data time series yang telah stasioner setelah dilakukan differencing sebanyak $d$ kali yaitu dengan menghitung selisih pengamatan dengan pengamatan sebelumnya dimana bentuk persamaan untuk model ARIMA adalah sebagai berikut:

$$
\begin{aligned}
& \phi_{p}(B)(1-B)^{d} Z_{t}=\theta_{0}+\theta_{q}(B) a \\
& y(\theta)=\sum_{j=0}^{2} \beta_{j}(\theta) x^{j}+\sum_{k=1}^{r} \beta_{2+k}(\theta)\left(x-K_{k}\right)_{+}^{2}
\end{aligned}
$$

Proses ARCH merupakan suatu proses stochastic dengan varian-varian kondisional yang tidak konstan masa lampau namun varian-varian nonkondisionalnya konstan. Model persamaan proses ARCH (p) yang dikembangkan oleh Engle yaitu model persamaan rerata dan ragam suatu data deret waktu yang dimodelkan secara simultan. Adapun persamaannya yaitu :

$$
\begin{aligned}
& \gamma_{t}=\beta_{0}+\beta_{1} X_{t}+\varepsilon_{t} \\
& \sigma_{t}^{2}=\alpha_{0}+\alpha_{1} \varepsilon_{t-1}^{2}+\cdots+\alpha_{p} \varepsilon_{t-p}^{2} \text { (persamaan ragam) }
\end{aligned}
$$

$\alpha_{0}>0, \alpha, \ldots, \alpha_{p} \geq 0 \varepsilon_{t} \mid I_{t} \sim N\left(0, \sigma_{t}^{2}\right)$

$\alpha_{0}, \alpha_{1}, \ldots, \alpha_{p}$ merupakan variabel-variabel positif dan $\varepsilon_{t}$ merupakan varibel random dengan mean nol dan varian $\sigma_{t}^{2}$ yang biasanya ditandai dengan kondisional $f_{t}(\varepsilon)$.

Model GARCH merupakan model yang dikembangkan oleh Bollerslev dari model ARCH dengan memasukkan unsur residual periode lalu dan ragam residual. Adapun model persamaan proses GARCH yaitu :

$$
\begin{gathered}
\sigma_{t}^{2}=\sigma_{1} \varepsilon_{1-t}^{2}+\cdots+\alpha_{p} \varepsilon_{t-1}^{2}+\beta_{1} \sigma_{t-1}^{2}+\cdots+\beta_{q} \sigma_{t-q}^{2} \\
\alpha_{0}>0, \alpha_{1}, \ldots, \alpha_{p} \beta_{q} \geq 0
\end{gathered}
$$

Dimana $\alpha_{0}, \alpha_{1}, \ldots, \alpha_{p}, \beta_{1}, \ldots, \beta_{q}$ merupakan parameter-parameter kontrol. $\varepsilon_{t}$ Adalah variabel random dengan mean nol dan varian $\sigma_{t}^{2}$. Persamaan tersebut menunjukkan ragam residual $\left(\sigma_{t}^{2}\right)$ tidak hanya dipengaruhi oleh kuadrat residual periode yang lalu $\left(\sigma_{t-p}^{2}\right)$, tetapi juga oleh ragam residual periode yang lalu $\left(\sigma_{t-q}^{2}\right)$.

Penelitian ini dilakukan pada bulan Januari hingga Februari 2020. Data yang digunakan dalam penelitian ini adalah data sekunder time series untuk data harga penutupan (closing price) saham harian milik bank BRI, Mandiri, BNI, dan BCA mulai periode 1 Januari 2017 hingga 31 Januari 2020 dengan jumlah pengamatan sebanyak 793 pengamatan harga saham harian masing-masing bank yang terdiri atas 5 hari untuk tiap minggunya (5 hari kerja efektif). Data bersumber dari website yahoo finance (www.finance.yahoo.com).

Langkah analisis dimulai dengan membuat time series plot dan menghitung statistik deskriptif harga penutupan masing-masing saham. Langkah berikutnya melakukan uji stasioneritas dengan menggunakan uji Dickey Fuller (DF). Data yang 
telah stasioner dibuat ACF dan PACF yang digunakan untuk pendugaan orde ARIMA. Berdasarkan ini, kemudian dilakukan estimasi, uji signifikansi parameter dan uji diagnosa residual. Model yang terbaik dipilih berdasarkan nilai MSD terekecil. Apabila data return saham belum memenuhi asumsi distribusi normal maka dilakukan deteksi outlier dan memodelkannya dengan model ARIMA terbaik.

Residual yang diperoleh dari model ARIMA terbaik diuji apakah terdapat efek heteroskedasticity (ARCH) dengan uji ARCH. Jika diketahui terdapat efek heteroskedasticity berarti layak dimodelkan dengan ARCH-GARCH. Orde ARCH dan GARCH diperoleh dengan melihat plot PACF residual kuadrat. Selanjutnya dilakukan estimasi dan uji signifikansi parameter ARCH-GARCH. Model ARCH-GARCH terbaik dipilih berdasarkan signifikansi parameter dan kemudian melakukan peramalan terhadap varians residual (volatilitas saham).

\section{Hasil dan Diskusi}

Statistik deskriptif dari harga penutupan saham perbankan adalah sebagai berikut Tabel 1. Statistik Deskriptif Harga Penutupan Saham

\begin{tabular}{lrrrr}
\hline & \multicolumn{1}{c}{ BBRI } & \multicolumn{1}{l}{ BBNI } & \multicolumn{1}{c}{ BBCA } & \multicolumn{1}{c}{ BMRI } \\
\hline Mean & 3478,142 & 7880,328 & 23992,60 & 7038,714 \\
\hline Median & 3475,000 & 7725,000 & 23450,00 & 7100,000 \\
\hline Maximum & 4740,000 & 10175,00 & 34375,00 & 9050,000 \\
\hline Minimum & 2335,000 & 5450,000 & 14950,00 & 5450,000 \\
\hline Std. Dev. & 610,320 & 1056,221 & 5026,884 & 713,332 \\
\hline Skewness & 0,011 & $-0,002$ & 0,091 & $-0,273$ \\
\hline Kurtosis & 1,982 & 2,286 & 2,074 & 2,462 \\
\hline
\end{tabular}

Saham BBRI memiliki potensi risiko yang paling rendah dibandingkan saham yang lain, dilihat dari standar deviasinya sebesar 610,320, sehingga BBRI lebih cocok untuk investor dengan tipe risk averse. Sedangkan saham BBCA memiliki potensi risiko yang paling tinggi dibandingkan saham yang lain, dilihat dari standar deviasinya sebesar 713,332, sehingga BBCA lebih cocok untuk investor dengan tipe risk taker.

1. Uji Kestasioneran Harga Penutupan Saham

Pengujian yang dilakukan untuk melihat kestasioneran data adalah dengan menggunakan uji akar unit, yang biasa disebut dengan Augmented Dickey Fuller Test dengan hipotesis.

$\mathrm{H}_{0}$ : Terdapat unit root/ Data tidak stasioner

$\mathrm{H}_{1}$ : Tidak terdapat unit root/ Data stasioner

Hasil pengujian yang diperoleh dari keempat saham pada level menunjukkan tidak ada data yang stasioner, oleh karena itu dilakukan pengujian pada $1^{\text {st }}$ difference yang hasilnya adalah sebagai berikut : 
Pemodelan dan Peramalan Harga Penutupan Saham Perbankan dengan... Dewi Novanti, Hajrul Multazam, Novira Layli Husna, dkk

Tabel 2. Hasil Pengujian Augmented Dickey Fuller pada $1^{\text {st }}$ Difference

\begin{tabular}{|c|c|c|}
\hline Saham & $\mathrm{ADF}$ & Prob. \\
\hline BBRI & $-27,706$ & 0,000 \\
\hline BBNI & $-28,390$ & 0,000 \\
\hline BBCA & $-22,994$ & 0,000 \\
\hline BMRI & $-29,071$ & 0,000 \\
\hline
\end{tabular}

Nilai p-value uji ADF masing-masing data harga penutupan saham lebih besar dari tingkat signifikansi 0,05 sehingga diputuskan menolak $\mathrm{H}_{0}$. Jadi, data harga penutupan saham telah stasioner terhadap mean.

2. Pemilihan Model ARIMA Terbaik

Pendugaan model digunakan plot ACF dan PACF dan untuk keempat saham menunjukkan lag yang signifikan. Secara umum, dugaan modelnya adalah AR atau MA. Setelah itu dilakukan estimasi masing-masing model dugaan ARIMA. Model yang terbaik dipilih berdasarkan kriteria signifikansi parameternya, nilai Adjusted R-Square terbesar serta nilai AIC dan SIC yang terkecil. Langkah yang sama juga dilakukan untuk tiga saham lainnya.

Tabel 3. Model ARIMA Terbaik

\begin{tabular}{ccccc}
\hline Saham & Model & $\begin{array}{c}\text { Adj. R- } \\
\text { Square }\end{array}$ & AIC & SIC \\
\hline BBRI & ARI([2,24,28),1,0) & 0,0261 & 10,875 & 10,884 \\
\hline BBNI & ARIMA([6,13],1,[6,13]) & 0,0136 & 12,766 & 12,795 \\
\hline BBCA & ARI([1,2],1,0) & 0,0212 & 14,073 & 14,091 \\
\hline BMRI & ARIMA $(2,1,4)$ & 0,0134 & 12,391 & 12,409 \\
\hline
\end{tabular}

3. Evaluasi Model

Model ARIMA yang terpilih kemudian akan diuji apakah menghasilkan residual yang random (white noise) dan bersifat normal. Model ARIMA saham BBRI, BBNI, BBCA, dan BMRI telah memenuhi asumsi residual White Noise yang menggunakan statitik uji Q-stat dimana pada kelima saham seluruh p-value Q-Stat untuk tiap lag-nya lebih besar dari $\alpha=0,05$ sehingga dapat disimpulkan residual bersifat acak.

4. Identifikasi Efek Heteroskedastik

Sebelum dibuat model ARCH-GARCH maka dilakukan uji Lagrange Multiplier (LM) terhadap residual kuadrat yang diperoleh dari model ARIMA terbaik yang dipilih dengan hipotesis

$\mathrm{H}_{0}$ : Tidak ada efek ARCH/GARCH (homokedastik)

$\mathrm{H}_{1}$ : Ada efek ARCH/GARCH (heteroskedastik)

Selanjutnya, hasil yang diperoleh sebagai berikut 
Tabel 4. Hasil Pengujian Efek Heteroskedastik

\begin{tabular}{lc}
\hline Saham & Prob. \\
\hline BBRI & 0,0102 \\
\hline BBNI & 0,9470 \\
\hline BBCA & 0,0000 \\
\hline BMRI & 0,0153
\end{tabular}

Hasil uji LM menunjukkan bahwa terdapat efek ARCH-GARCH terhadap residual harga penutupan saham BBRI, BBCA, dan BMRI. Dengan demikian, analisis ARCHARCH-GARCH layak digunakan. Pada saham BBNI tidak diperoleh adanya efek ARCH-GARCH karena residual saham BBNI telah bersifat homoskedastik sehingga tidak perlu dilakukan analisis ARCH-GARCH.

5. Estimasi model ARCH-GARCH

Model ARIMA yang bersifat Heterokedastik dilakukan analisis dengan ARCHGARCH. Model ARIMA dengan ARCH-GARCH terbaik dipilih berdasarkan kriteria signifikansi parameter. Model yang diestimasi adalah saham BBRI, BBCA, dan BMRI. Berikut merupakan model ARIMA terbaik dan ARCH-GARCH untuk saham BBRI, BBCA, dan BMRI.

Tabel 5. Estimasi dan Signifikansi Model ARCH-GARCH Terbaik

\begin{tabular}{|c|c|c|c|c|}
\hline Saham & Model & Parameter & Esimasi & $p$-value \\
\hline \multirow[t]{5}{*}{ BBRI } & \multirow{5}{*}{$\begin{array}{l}\text { ARI([2,24,28),1,0)- } \\
\operatorname{ARCH}(1)\end{array}$} & $\Phi_{2}$ & $-0,072$ & 0,0093 \\
\hline & & $\Phi_{24}$ & $-0,102$ & 0,0002 \\
\hline & & $\Phi_{28}$ & $-0,102$ & 0,0001 \\
\hline & & $\alpha_{0}$ & 2136,322 & 0,0000 \\
\hline & & $\alpha_{1}$ & 0,182 & 0,0000 \\
\hline \multirow[t]{5}{*}{ BBCA } & \multirow{5}{*}{$\begin{array}{l}\text { ARI([1,2],1,0)- } \\
\operatorname{GARCH}(1,1)\end{array}$} & $\Phi_{1}$ & $-0,150$ & 0,0007 \\
\hline & & $\Phi_{2}$ & $-0,092$ & 0,0228 \\
\hline & & $\alpha_{0}$ & 22321,040 & 0,0000 \\
\hline & & $\alpha_{1}$ & 0,156 & 0,0000 \\
\hline & & $\beta_{1}$ & 0,553 & 0,0000 \\
\hline \multirow[t]{5}{*}{ BMRI } & \multirow{5}{*}{$\begin{array}{l}\text { ARIMA(2,1,4)- } \\
\operatorname{GARCH}(1,1)\end{array}$} & $\Phi_{2}$ & $-0,066$ & 0,0991 \\
\hline & & $\theta_{4}$ & $-0,117$ & 0,0005 \\
\hline & & $\alpha_{0}$ & 92,994 & 0,0016 \\
\hline & & $\alpha_{1}$ & 0,017 & 0,0015 \\
\hline & & $\beta_{1}$ & 0,976 & 0,0000 \\
\hline
\end{tabular}

Saham BBCA memiliki model GARCH $(1,1)$ sedangkan saham BBRI memiliki model ARCH (1). Hal ini berarti varians residual saham BBCA pada waktu $t$ dipengaruhi oleh residual kuadrat dan varians residual pada waktu $t-1$, sedangankan 
pada saham BBRI, varians residual saham pada waktu t hanya dipengaruhi oleh residual kuadrat pada waktu t-1. Seluruh parameter dalam model signifikan sehingga dapat dibuat model volatilitasnya.

6. Peramalan

Berdasarkan keempat grafik peramalan di atas, masing-masing peramalan saham perbankan sudah mengikuti grafik data asli perbankan yang ada. Sehingga dapat dikatakan bahwa data hasil forecast statis sudah baik untuk digunakan. Jika menggunakan data forecast dinamis, maka akan menghasilkan grafik forecast yang tidak mengikuti grafik data asli.

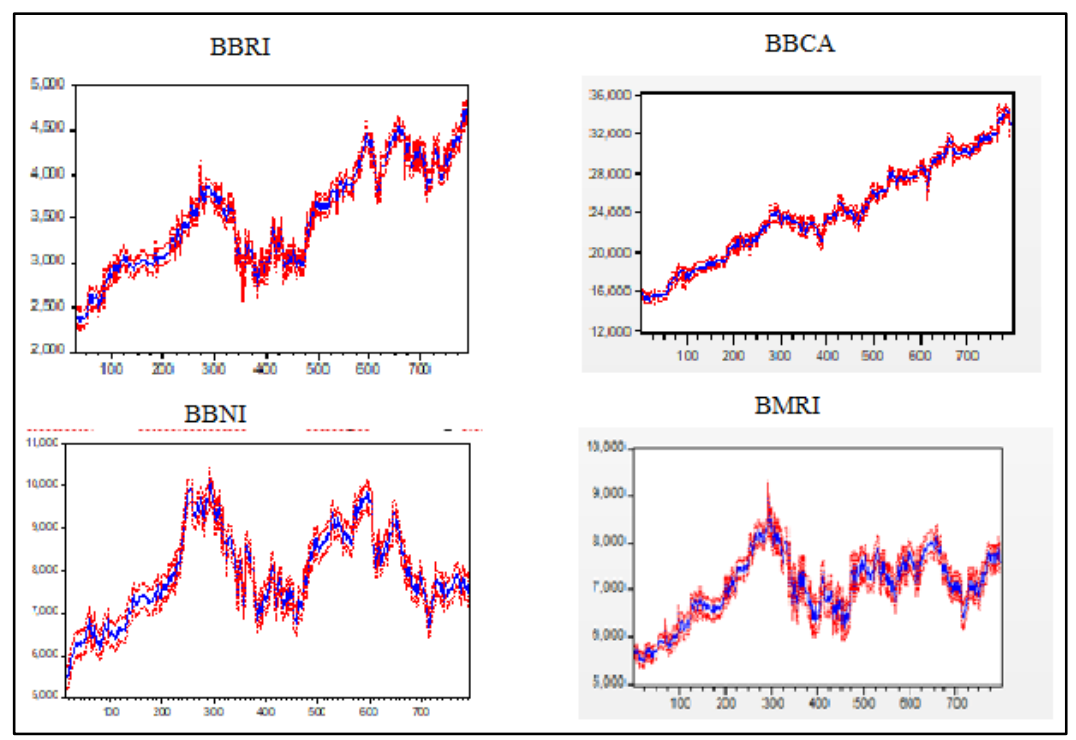

Gambar 1. Grafik hasil forecast masing-masing bank

Tabel 6. Nilai RMSE, MAE, dan MAPE untuk Masing-Masing Hasil Forecast

\begin{tabular}{crrrr}
\hline Data & \multicolumn{1}{c}{ BBRI } & \multicolumn{1}{c}{ BBNI } & \multicolumn{1}{c}{ BBCA } & \multicolumn{1}{c}{ BMRI } \\
\hline RMSE & 56,156 & 143,093 & 274,557 & 118,330 \\
\hline MAE & 40,124 & 101,798 & 190,445 & 83,673 \\
\hline MAPE & 1,159 & 1,287 & 0,807 & 1,184 \\
\hline
\end{tabular}

Berdasarkan hasil peramalannya, menunjukkan bahwa saham BBRI pada tanggal 3 Febuari 2020 mengalami peningkatan dari pada saham closing price sebelumnya pada tanggal 31 Januari 2020 sebesar Rp. 4.060 menjadi Rp. 4.469 dengan kenaikan sebesar 10,07\%. Kemudian untuk saham BBCA mengalami kenaikan saham dari Rp. 32.400 menjadi Rp. 32.648 atau sebesar 0,765\%. Begitu pula untuk saham BMRI mengalami peningkatan yaitu dari closing price sebelumnya sebesar Rp. 7.550 menjadi Rp. 7.559 atau sebesar 0,119\%, Dan untuk saham BBNI mengalami penurunan dari sebesar Rp. 7.200 menjadi Rp. 7.189 atau penurunan sebesar 0,152\%. Maka saham BBNI merupakan satu-satunya saham yang mengalami penurunan untuk data saham closing 
price pada tanggal 3 Februari 2020. Dilihat berdasarkan nilai kenaikan harga saham, maka saham terbaik yang dapat dipilih oleh investor adalah saham BBRI karena memilik kenaikan terbesar yaitu sebesar $10 \%$ diikuti oleh saham BBCA dan BMRI. Sedangkan saham yang seharusnya dihindari oleh investor menurut model yang terbentuk adalah saham BBNI karena mengalami penurunan harga sahamnya.

\section{Kesimpulan}

Berdasarkan penelitian yang telah dilakukan maka dapat diambil kesimpulan sebagai berikut :

a) Model terbaik untuk meramalkan closing price saham saham BBRI adalah dengan model ARI([2,24,28),1,0)-ARCH(1) dengan hasil peramalan sebesar Rp. 4.469 atau mengalami kenaikan sebesar $10,07 \%$.

b) Model terbaik untuk meramalkan closing price saham saham BBCA adalah dengan model model ARI([1,2],1,0)-GARCH(1,1) dengan hasil peramalan sebesar Rp. 32.648 atau mengalami kenaikan sebesar $0,765 \%$..

c) Model terbaik untuk meramalkan closing price saham saham BMRI adalah dengan model model ARIMA(2,1,4)-GARCH(1,1) dengan hasil peramalan sebesar Rp. 7.559 atau mengalami kenaikan sebesar $0,119 \%$.

d) Model terbaik untuk meramalkan closing price saham saham BBNI adalah dengan model model ARIMA([6,13],1,[6,13]). dengan hasil peramalan sebesar Rp. 7.189 atau mengalami penurunan sebesar $0,152 \%$.

Selanjutnya, beberapa saran yang dapat penulis berikan, yaitu :

a) Berdasarkan hasil peramalan yang sudah didapatkan, penulis menyarankan untuk memilih saham bank BRI karena memiliki kenaikan terbesar yaitu sebesar 10,07\%.

b) Diharapkan pada penelitian kedepannya terdapat suatu permodelan harga saham yang bisa lebih akurat.

c) Diharapkan pada penelitian kedepannya akan terdapat suatu penelitian yang dapat menghasilkan suatu hasil permodelan yang dapat mengestimasi lebih dari 1 periode harga saham dan tetap mengikuti grafik data asli harga saham tersebut.

\section{Daftar Pustaka}

[1] Engle, R.F. Autoregressive Conditional Heteroscedasticity with estimates of the variance of united kingdom inflation. Journal of Econometrics. 50: 987-1008, 1982.

[2] Ginting, Suriani dan Suriany. Analisis Faktor-Faktor yang Mempengaruhi Harga Saham pada Perusahaan Manufaktur di Bursa Efek Indonesia. Skripsi. Medan : STIE Mikroskil, 2013.

[3] Nastiti, Ayu, K. L., dan Suharsono, A. Analisis Volatilitas Saham Perusahaan Go Public dengan Metode ARCH-GARCH. Skripsi. Surabaya : Institut Teknologi Sepuluh Nopember (ITS), 2012. 
[4] Yolanda, N. B., Nainggolan, N. dan H. A. H. Kamalig. Penerapan Model ARIMAGARCH Untuk Memprediksi Harga Saham Bank BRI. Skripsi. Manado : Universitas Sam Ratulangi, 2017.

[5] https://finance.yahoo.com/quote/BBRI.JK/history?p=BBRI.JK [Diakses terakhir tanggal 9 Februari 2022].

[6] https://finance.yahoo.com/quote/BMRI.JK/history?p=BMRI.JK [Diakses terakhir tanggal 9 Februari 2022].

[7] https://finance.yahoo.com/quote/BBNI.JK/history?p=BBNI.JK [Diakses terakhir tanggal 9 Februari 2022].

[8] https://finance.yahoo.com/quote/BBCA.JK/history?p=BBCA.JK [Diakses terakhir tanggal 9 Februari 2022]. 
Pemodelan dan Peramalan Harga Penutupan Saham Perbankan dengan...

Dewi Novanti, Hajrul Multazam, Novira Layli Husna, dkk

\section{Lampiran}

Peramalan Data Harga Closing Saham Bank BRI

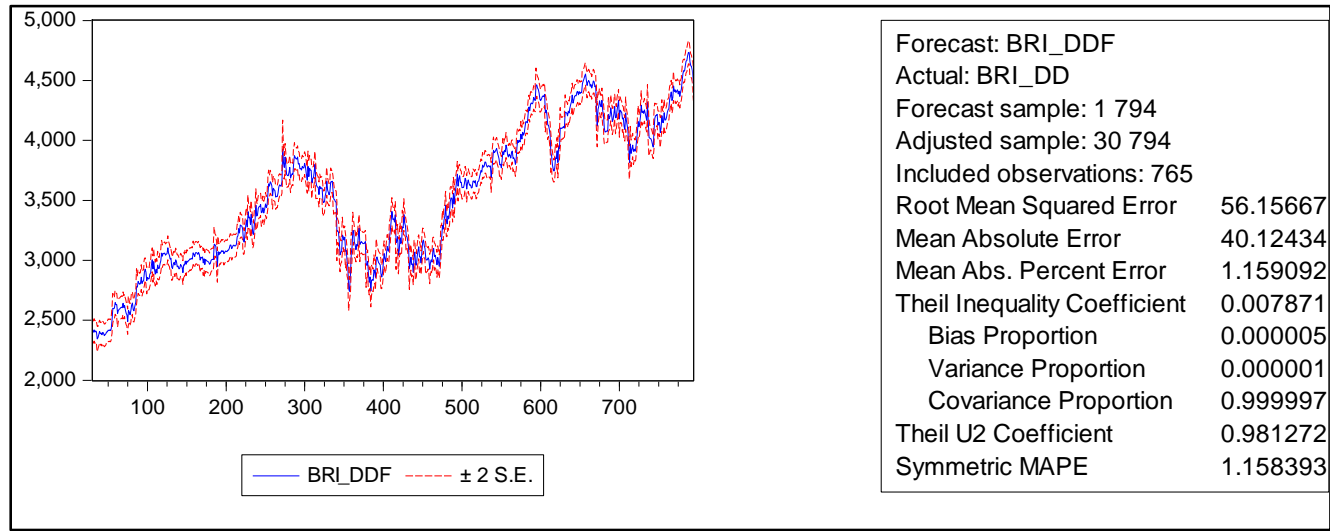

Peramalan Data Harga Closing Saham Bank BNI

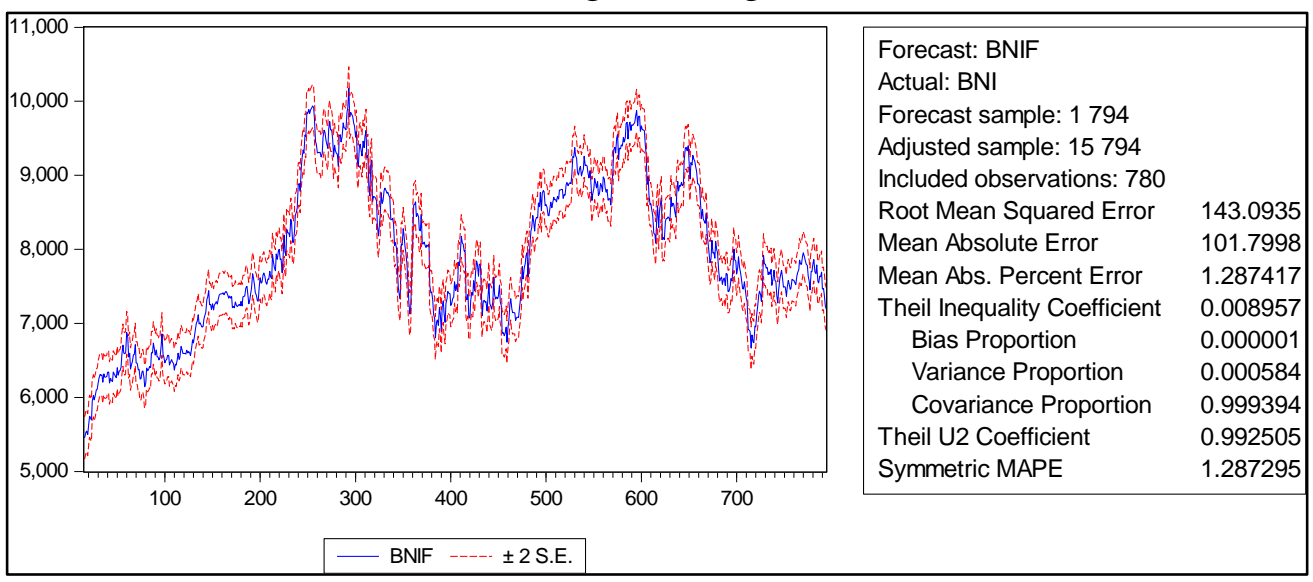

Peramalan Data Harga Closing Saham Bank BCA

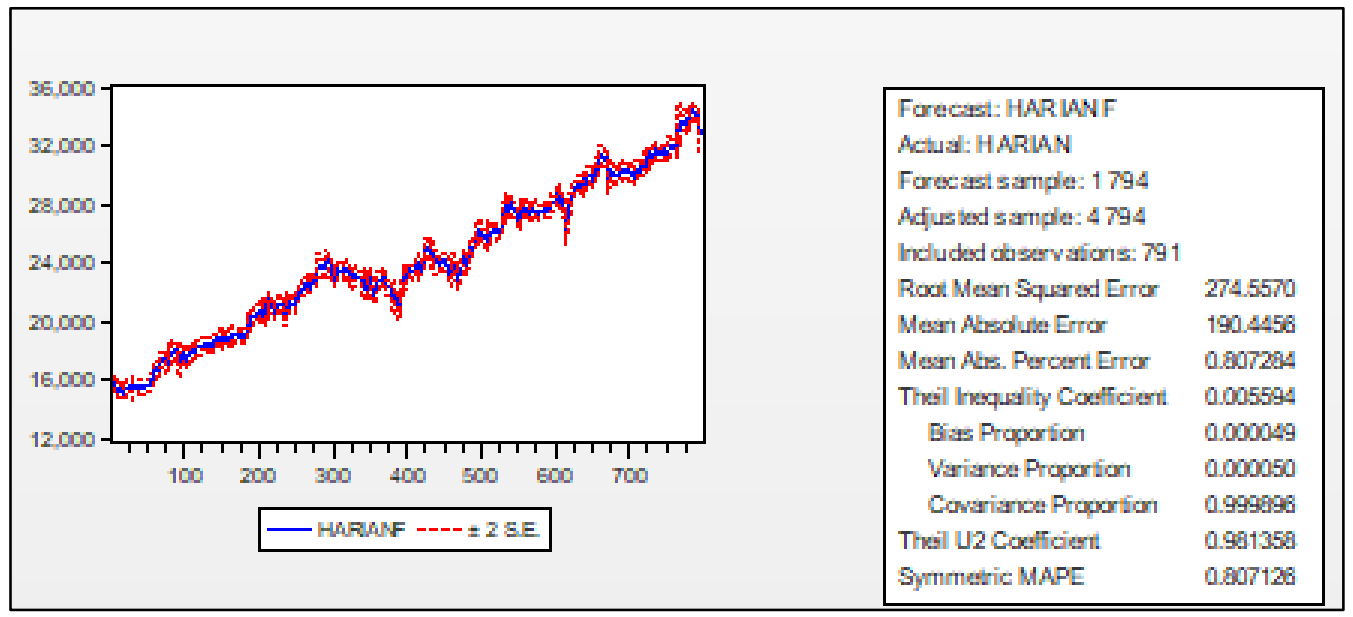


Pemodelan dan Peramalan Harga Penutupan Saham Perbankan dengan...

Dewi Novanti, Hajrul Multazam, Novira Layli Husna, dkk

Peramalan Data Harga Closing Saham Bank Mandiri

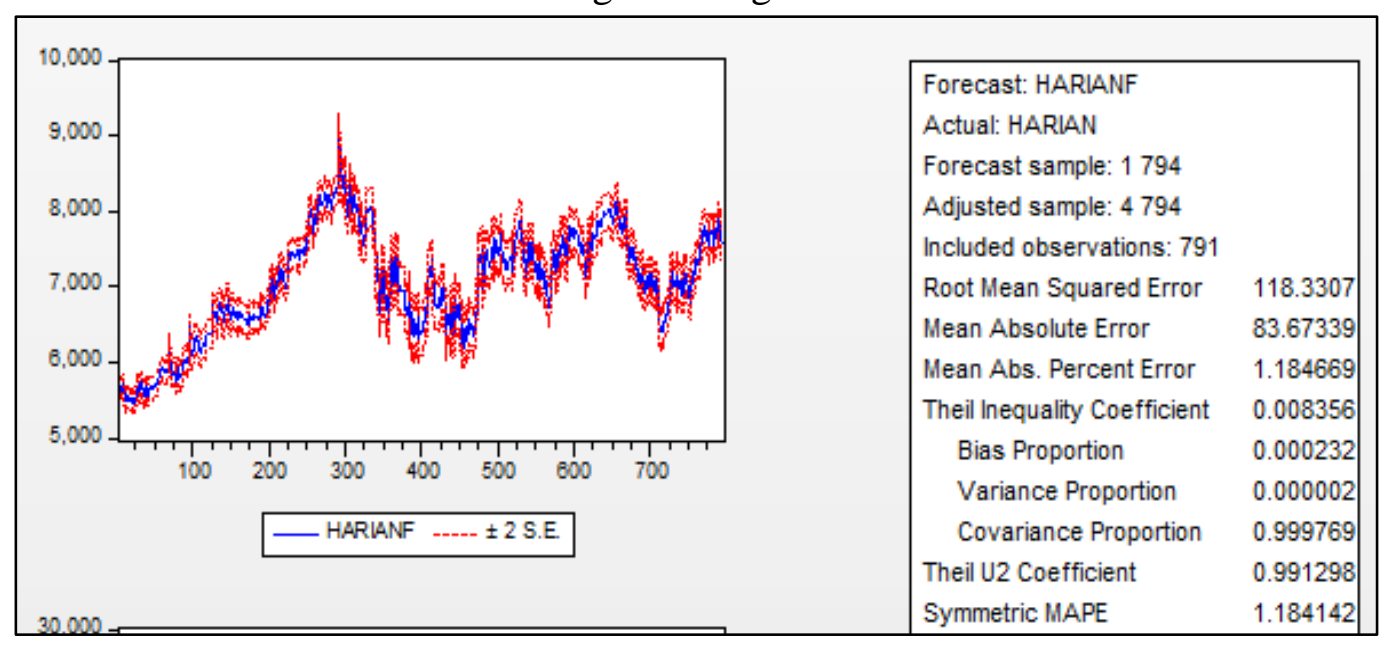

